\title{
Active chlorine and charcoal affect the in vitro culture of Bambusa vulgaris
}

\author{
El cloro y el carbón activos afectan el cultivo in vitro de Bambusa vulgaris
}

\author{
Fernanda Cardoso Furlan a, Natália Helena Gavilan a, Alex Zichner Zorz a,

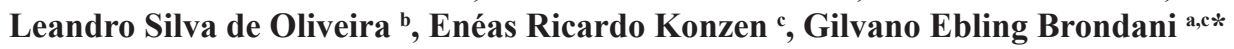 \\ a Federal University of Mato Grosso (UFMT), College of Forestry, Fernando Corrêa da Costa Avenue, 2367, \\ Cuiabá, MT, 78060-900, Brazil. \\ ${ }^{\mathrm{b}}$ Federal University of Minas Gerais (UFMG), Institute of Agronomic Sciences, 39404-547, Montes Claros, MG, Brazil. \\ *Corresponding author: ${ }^{\mathrm{c}}$ Federal University of Lavras (UFLA), Department of Forest Sciences, \\ P.O. Box 3037, 37200-000, Lavras, MG, Brazil, gebrondani@gmail.com
}

\begin{abstract}
SUMMARY
We evaluated the supplementation of the MS culture medium with active chlorine and activated charcoal for the in vitro culture of Bambusa vulgaris. Lateral shoots were collected from field-cultivated plants to obtain explants, which consisted of nodal segments of 1-2 cm length, containing one axillary bud. The MS culture medium was supplemented with the following treatments: $\mathrm{E}_{1}=0.004 \% \mathrm{v} \mathrm{v}$ of active chlorine $+4 \mathrm{~g} \mathrm{~L}^{-1}$ of charcoal; $\mathrm{E}_{2}=0.004 \% \mathrm{v} \mathrm{v}^{-1}$ of active chlorine; $\mathrm{E}_{3}=4 \mathrm{~g} \mathrm{~L}^{-1}$ charcoal and $\mathrm{E}_{4}=$ control (no active chlorine and no charcoal). The percentage of oxidation, fungal and bacterial contamination, explant establishment, survival, sprout and adventitious rooting were evaluated every $21 \mathrm{~d}$, during $63 \mathrm{~d}$. The use of active chlorine reduced the fungal $(28 \%)$ and bacterial (38\%) contamination, being the treatment with the highest percentage of established explants $(16 \%)$, survival $(68 \%)$ and sprout induction $(95 \%)$ after $63 \mathrm{~d}$. After 36 days from the beginning of the multiplication stage, some explants presented spontaneous rooting, without the application of plant growth regulators. An anatomical analysis of sprouts and roots revealed the presence of meristematic zones. Furthermore, it indicated that the emergence of adventitious roots occurred from the nodal region in association with axillary buds. Our results contribute toward the development of more efficient protocols for the in vitro propagation of B. vulgaris, from which we recommend using active chlorine for further assessments.
\end{abstract}

Key words: bamboo, asepsis, contamination, sprout induction, micropropagation.

\section{RESUMEN}

En el estudio se evaluó el suplemento de cloro activo y carbono activado en el cultivo in vitro de Bambusa vulgaris. Brotes laterales fueron colectados de las plantas cultivadas en el campo para obtener explantes. Los explantes consistieron en segmentos nodales de 1-2 $\mathrm{cm}$ de longitud que contenían una yema axilar. El medio MS se suplementó con los siguientes tratamientos: $\mathrm{E}_{1}=0,004 \% \mathrm{v} \mathrm{v}^{-1}$ de cloro activo $+4 \mathrm{~g} \mathrm{~L}^{-1}$ de carbón; $\mathrm{E}_{2}=0,004 \% \mathrm{v} \mathrm{v}^{-1}$ de cloro activo; $\mathrm{E}_{3}=4 \mathrm{~g} \mathrm{~L}^{-1}$ de carbón y $\mathrm{E}_{4}=$ control (sin suplemento con cloro activo y sin carbón). El porcentaje de oxidación, la contaminación por hongos y bacterias, el establecimiento del explante, la supervivencia, la inducción del brote y enraizamiento se evaluaron durante 63 días. El uso de cloro activo redujo la contaminación por hongos (28 \%) y bacterianas (38\%), siendo el tratamiento con mayor porcentaje de explantes establecidos (16\%), supervivencia (68\%) y inducción de brotes $(95 \%)$. Después de 36 días, algunos explantes presentaron enraizamiento espontáneo, sin aplicación de reguladores de crecimiento. Un análisis anatómico de los brotes y raíces mostró zonas meristemáticas, la conexión entre el sistema vascular del tallo y las hojas y la aparición de raíces adventicias en la región nodal en asociación con los brotes axilares. Los resultados contribuyen al desarrollo de protocolos más eficientes para la propagación in vitro de B. vulgaris, de los cuales se recomienda el uso de cloro activo para futuras evaluaciones.

Palabras clave: bambú, asepsia, contaminación, inducción de brotes, micropropagación.

\section{INTRODUCTION}

The increasing demand of woody biomass and derivatives for developing products into the market has promoted the development of new methods and biotechnology approaches for breeding forest species. Viable alternative species have been searched and analyzed for supplying the industry demands. Bamboos fit as such option for producing sustainable biomass (Mudoi et al. 2013, Singh et al. 2013). One species to be highlighted is Bambusa vulgaris Schrad. ex J. C. Wendl, widely cultivated where its main uses are for energy, paper and cellulose (Ramanayake et $a l .2006$ ) and with potential application in the food industry as flours and as source of fibers. 
The supply of saplings for large-scale production systems of various species is frequently based on their propagation by seeds. Bamboos such as B. vulgaris, however, are difficult to propagate by seeds as they rarely produce them. Generally, bamboos are propagated through vegetative methods, including tillering, cuttings and culm sectioning. Such strategies, however, are expensive, time-consuming and provide low adventitious rooting, which have limited their application for commercial purposes so far (Singh et al. 2013).

The in vitro propagation of bamboos is a viable alternative for large-scale production of clonal plants from selected materials, as it provides new plants in a short period, independently of the seasonality (Jiménez et al. 2006, Mudoi et al. 2013, Singh et al. 2013). In bamboo, direct organogenesis has been partially achieved from segmental nodes with axillary dormant buds (Jiménez et al. 2006, Bakshi et al. 2015). Despite all efforts, to establish an efficient protocol for growing plants from such explants remains a challenge. Usually, high microbial contamination has been reported, including endophytic fungi, challenging the supply of commercial demands (Singh et al. 2013).

The contamination might be diminished by using efficient methods for asepsis of the explants before inoculation, coupled with the supplementation of the culture medium with germicides, fungicides and antibiotics (Singh et al. 2013). Among the germicides, active chlorine has been widely used for the asepsis prior the in vitro inoculation and supplemented to the culture medium to reduce the contamination by microorganisms in herbaceous and woody species (Brondani et al. 2013, Brondani et al. 2017). Moreover, active chlorine has been considered less toxic to plant tissues than other compounds in certain working conditions (Teixeira et al. 2006, Brondani et al. 2013).

Another recurring factor in the in vitro cultivation of bamboos involves the darkening (i.e., tissue necrosis) of tissues (oxidation), which might be associated with mechanisms of cicatrization in response to injuries caused by the explant sectioning during inoculation, reducing in vitro establishment (Mudoi et al. 2013). Among the compounds that might be used for minimizing tissue oxidation, activated charcoal is a suitable option (George et al. 2008, Singh et al. 2013, Silva et al. 2015).

Our work was aimed at evaluating the effect of the supplementation of the MS culture medium with active chlorine and activated charcoal in the in vitro establishment of explants from adult individuals of $B$. vulgaris. With the experiments, we wanted to achieve higher rates of established explants for improving further steps of the in vitro protocols, such as multiplication and adventitious rooting. The anatomical origin of sprouts and roots are also discussed, based on histological sections of $B$. vulgaris explants.

\section{METHODS}

Selection and preparation of explants. Lateral shoots containing dormant buds originated from the median part (central region in length) of the culm were collected from B. vulgaris plants (approximately seven years old) cultivated under field conditions. The shoots were placed in opaque plastic bags to prevent exposition to light and dehydration and, afterward, transported (period of $48 \mathrm{~h}$ ) to the laboratory for the experiments.

From the materials collected, leaf sheaths near each axillary bud were removed (figure 1A-B). After, the shoots

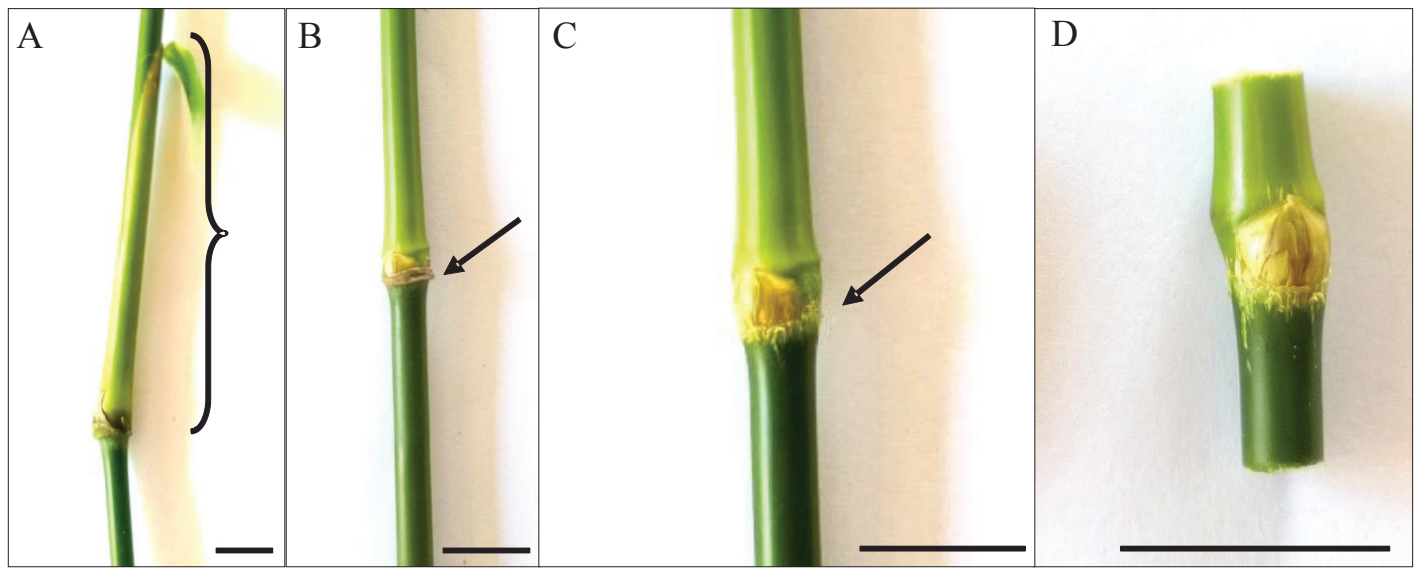

Figure 1. Detail of the preparation of explants of Bambusa vulgaris. (A) Lateral shoot, highlighting the presence of the leaf sheath. (B) Propagule without the leaf sheath. The black arrow indicates the axillary bud. (C) Propagule with arrow indicating the peeled area.

(D) Standardized nodal segments for in vitro inoculation. Bar $=1 \mathrm{~cm}$.

Detalle de la preparación de explantes de Bambusa vulgaris. (A) Brote lateral, destacando la presencia de la vaina foliar. (B) Segmento nodal sin la vaina foliar. La flecha negra indica la yema axilar. (C) Segmento nodal con flecha indicando el área. (D) Segmento nodal estandarizado para la inoculación in vitro. Barra $=1 \mathrm{~cm}$. 
were placed in distilled water containing commercial neutral detergent. The adjacent area to each axillary bud was peeled (figure 1C). Axillary buds were washed with a sponge; and the nodal segments were sectioned to $1-2 \mathrm{~cm}$ in length (explants) (figure 1D). The nodal segments were subsequently rinsed in distilled water before the asepsis treatment.

Asepsis of the explants. Operating in a laminar flow chamber, the explants (figure 1D) were placed in a hydroalcoholic solution $\left(70 \% \mathrm{v} \mathrm{v}^{-1}\right)$ for $1 \mathrm{~min}$ and rinsed with distilled and sterilized water. The explants were later placed in a $2.0-2.5 \%\left(\mathrm{p} \mathrm{p}^{-1}\right)$ solution of active chlorine $(\mathrm{NaOCl})$ with commercial neutral detergent $\left(0.05 \% \mathrm{v} \mathrm{v}^{-1}\right)$ for $10 \mathrm{~min}$. Finally, the explants were rinsed five times in distilled and sterilized water. The explants were vertically inoculated in test tubes containing the culture medium. The axillary bud of each explant was placed in direct contact with the culture medium.

Treatments and experimental design. The effects of chlorine $\left(\right.$ Anhambi $\left.^{\circledR}\right)$ and activated charcoal $\left(\right.$ Alphatec $\left.^{\mathbb{R}}\right)$ supplemented in MS culture medium (Murashige and Skoog 1962) were tested for the in vitro establishment of B. vulgaris. Treatments consisted of: $\mathrm{E}_{1}=0.004 \%$ of active chlorine $\left(\mathrm{p} \mathrm{p}^{-1}\right.$, with $\left.\mathrm{NaOCl}\right)+4 \mathrm{~g} \mathrm{~L}^{-1}$ of charcoal; $\mathrm{E}_{2}=$ $0.004 \%$ of active chlorine; $\mathrm{E}_{3}=4 \mathrm{~g} \mathrm{~L}^{-1}$ of charcoal; and $\mathrm{E}_{4}=$ explants cultivated in culture medium without active chlorine and charcoal (control). The explants were subcultivated in the same culture medium after 21, 42 and $63 \mathrm{~d}$, maintaining the same treatments.

The explants were inoculated in test tubes $(2 \times 10 \mathrm{~cm})$ containing $5 \mathrm{~mL}$ of the culture medium which was prepared with distilled water, $6 \mathrm{~g} \mathrm{~L}^{-1}$ of agar, $20 \mathrm{~g} \mathrm{~L}^{-1}$ of sucrose $\left(\mathrm{C}_{12} \mathrm{H}_{22} \mathrm{O}_{11}\right)$ and $2 \mathrm{mg} \mathrm{L}^{-1}$ of BAP (6-benzylaminopurine; Sigma $\left.^{\mathbb{Q}}\right)$. The medium was supplemented with $2 \mathrm{mg} \mathrm{L}^{-1}$ of the fungicide benomyl [Methyl 1-(butylcarbamoyl)-2-benzimidazolecarbamate; Bayer ${ }^{\circledR}$. After $21 \mathrm{~d}$, the explants were transferred to culture medium with the same formula, nonetheless in absence of the fungicide. The explants were subcultivated in this culture medium for $63 \mathrm{~d}$.

The experiment was conducted in a completely randomized design in $2^{2}$ factorial with repeated measures at 0,21 , 42 and 63 days (i.e., split-plot in time). Four concentrations of active chlorine and charcoal $\left(\mathrm{E}_{1}, \mathrm{E}_{2}, \mathrm{E}_{3} \mathrm{e} \mathrm{E}_{4}\right)$ and four periods of time $(0,21,42$ and $63 \mathrm{~d})$ were tested. Each test tube containing an inoculated explant was considered as one replicate. In total, we analyzed 50 replicates per treatment.

At each period of time $(0,21,42$ and $63 \mathrm{~d})$ we evaluated the percentage of oxidization, fungal and bacterial contamination, explant establishment and survival, the percentage of sprout induction and adventitious rooting. We considered an explant as established when it was absent from fungal or bacterial contamination and without oxidation. Conversely, we considered survival the number of explants that were absent of fungi, even though it might have had bacterial contamination or oxidation.
Bud multiplication. At 63 days of in vitro cultivation, we selected explants with more than three sprouts per nodal region (with the axillary bud). From this explant source, we isolated the sprouts produced by sectioning them to the length of $1 \mathrm{~cm}( \pm 0.5 \mathrm{~cm})$. The explants were afterwards inoculated in culture medium for $63 \mathrm{~d}$, being transferred every 21 days to new culture medium prepared in the same conditions. The explants were inoculated in test tubes $(2 \times 10 \mathrm{~cm})$ containing $5 \mathrm{~mL}$ of culture medium prepared with distilled water, $6 \mathrm{~g} \mathrm{~L}^{-1}$ of agar, $20 \mathrm{~g} \mathrm{~L}^{-1}$ of sucrose and $2 \mathrm{mg} \mathrm{L}^{-1}$ of BAP (6-benzylaminopurina).

Acclimatization. The root development was observed under in vitro conditions, followed by a simple acclimatization process to maximize the survival rate. The plants were cultivated in white plastic cups with $30 \mathrm{~mL}$ capacity, containing substrate composed by a mixture of parboiled rice husk and vermiculite $\left(1: 1 ; \mathrm{p} \mathrm{p}^{-1}\right)$, and submitted to ex vitro conditions, in growth room with controlled temperature and light, as a final step for acclimatization.

Incubation conditions. The culture medium was adjusted to pH 5.8 and sterilized in autoclave at $121^{\circ} \mathrm{C}\left(\sim 1.0 \mathrm{kgf} \mathrm{cm}^{-2}\right)$ for $20 \mathrm{~min}$. The explants were cultivated in growth room at $25^{\circ} \mathrm{C}\left( \pm 2{ }^{\circ} \mathrm{C}\right)$, photoperiod of $16 \mathrm{~h}$ and $32 \mu \mathrm{mol} \mathrm{m}^{-2} \mathrm{~s}^{-1}$ of light intensity (provided by white fluorescent lamps).

Histological analyses. Samples of nodal segments of B.vulgaris were fixed in a modified formaldehyde and glutaraldehyde solution (glutaraldehyde $1 \%$, paraformaldehyde $4 \%$ in sodium phosphate buffer, $\mathrm{NaH}_{2} \mathrm{PO}_{4} \cdot \mathrm{H}_{2} \mathrm{O}$, $0.1 \mathrm{M}, \mathrm{pH}$ 7.2) (Karnovsky 1965) and submitted to six vacuum series $(-600 \mathrm{mmHg})$ for $30 \mathrm{~min}$ each. The samples were stored for 30 days at $4{ }^{\circ} \mathrm{C}$. Samples were placed in infiltration medium (Historesin ${ }^{\circledR}$, Leica) for $24 \mathrm{~h}$ and prepared according to the manufacturer's instructions, remaining 28 days at $24{ }^{\circ} \mathrm{C}$. The blocks containing the samples were sectioned longitudinally or transversally to $10 \mu \mathrm{m}$ thickness using the automatic rotary microtome Microm HM 355S (Thermo Scientific). Each section was stained with toluidine blue $\left(0.05 \%, \mathrm{v} \mathrm{v}^{-1}\right)$ in sodium phosphate buffer and citric acid (Sakai 1973) for $30 \mathrm{~min}$ and mounted on histological blades with synthetic resin $\left(\right.$ Entellan $\left.^{\circledR}\right)$. The histological sections were analyzed and photographed in optic microscope (Opton) and the images were captured in micrometric scale. A descriptive analysis was performed on each sample, aimed at identifying the disposition of the tissues connecting the axillary buds and nodes, the region of the adventitious root emergence and evidences for meristematic zones.

Statistical analyses. The data were submitted to Hartley's test $(P<0.05)$ and Shapiro-Wilk $(P<0.05)$ and transformed, when necessary, according to the Box-Cox test. The data were submitted to analysis of variance (ANOVA, $P<0.05$ ). The data obtained from quantitative factors 
were analyzed through polynomial regression (logistic or exponential), the best models were adopted for graphic representation.

\section{RESULTS}

In vitro oxidation, contamination and establishment. The ANOVA revealed an interaction $(P<0.05)$ between the concentration of active chlorine and charcoal with the time-interval as regards the variables oxidation, fungal and bacterial contamination, established explants, survival and sprout induction (data not shown). Oxidation was observed as the progressive darkening (i.e., necrosis) of the B. vulgaris explants. After 42 days of cultivation, all explants $(100 \%)$ exhibited oxidation, including the explants treated with activated charcoal (figure 2A, figure 3 ).
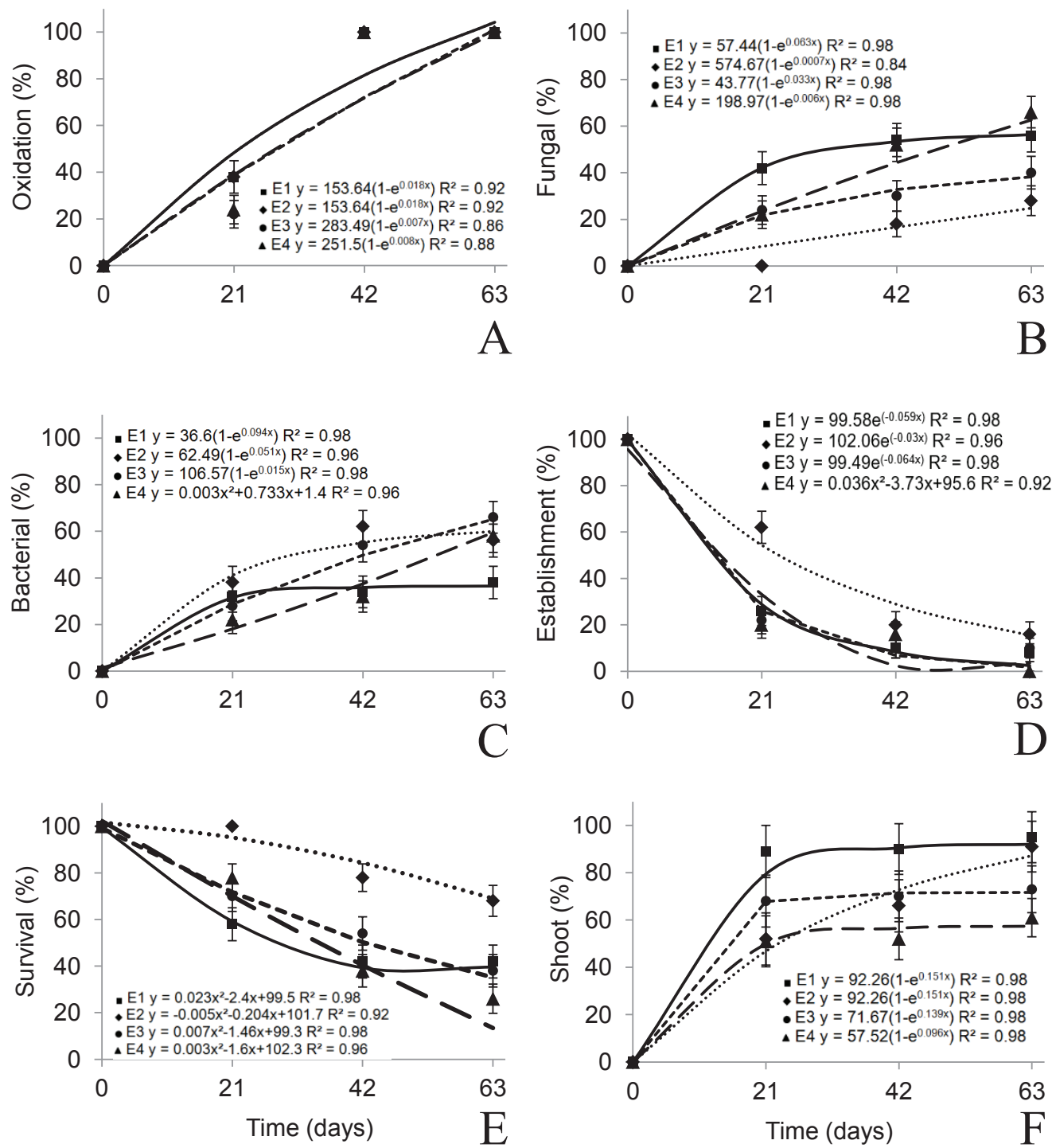

Figure 2. Results of the in vitro establishment of nodal segments (explants) of Bambusa vulgaris considering the MS medium supplemented with different combinations of active chlorine and activated charcoal: $\mathrm{E}_{1}=0.004 \% \mathrm{v} \mathrm{v}^{-1}$ of active chlorine $+4 \mathrm{~g} \mathrm{~L}^{-1}$ of charcoal; $\mathrm{E}_{2}=0.004 \% \mathrm{v} \mathrm{v}^{-1}$ of active chlorine; $\mathrm{E}_{3}=4 \mathrm{~g} \mathrm{~L}^{-1}$ of charcoal; and $\mathrm{E}_{4}=$ explants cultivated in culture medium without active chlorine and charcoal (control). The explants were subcultivated in the same culture medium after 21, 42 and $63 \mathrm{~d}$, maintaining the same treatments. (A) Percentage of oxidation. (B) Percentage of fungal contamination. (C) Percentage of bacterial contamination. (D) Percentage of established explants. (E) Percentage of survival. (F) Percentage of explants that induced shoots.

Resultados del establecimiento in vitro de segmentos nodales (explantes) de Bambusa vulgaris considerando el medio MS suplementado con diferentes combinaciones de cloro activo y carbón activado: $\mathrm{E}_{1}=0,004 \% \mathrm{v} \mathrm{v}^{-1}$ de cloro activo $+4 \mathrm{~g} \mathrm{~L}^{-1}$ de carbón; $\mathrm{E}_{2}=0,004 \% \mathrm{v} \mathrm{v}$ de cloro activo; $\mathrm{E}_{3}=4 \mathrm{~g} \mathrm{~L}^{-1}$ de carbón y $\mathrm{E}_{4}=$ control (sin suplemento con cloro activo y sin carbón). Los explantes fueron subcultivados en el mismo medio de cultivo después de 21, 42 y 63 días, manteniendo los mismos tratamientos. (A) Porcentaje de oxidación. (B) Porcentaje de contaminación por hongos. (C) Porcentaje de contaminación bacteriana. (D) Porcentaje de explantes establecidos. (E) Porcentaje de supervivencia. (F) Porcentaje de explantes que presentaron brotes. 




Figure 3. Explants of Bambusa vulgaris presenting oxidation after 42 days of in vitro cultivation. The arrow indicates that the oxidation showed no spreading over the axillary buds. $\mathrm{Bar}=1 \mathrm{~cm}$.

Explantes de Bambusa vulgaris oxidado después de 42 días de cultivo in vitro. La flecha indica que la oxidación no mostró propagación sobre los brotes axilares. Barra $=1 \mathrm{~cm}$.

The supplementation of the culture medium with active chlorine diminished fungal contamination (figure $2 \mathrm{~B}$ ). After 63 days of cultivation, the percentage of fungal contamination was reduced in $28 \%$ for the treatment containing only active chlorine $\left(0.004 \%, \mathrm{E}_{2}\right)$. The treatment with active chlorine coupled with charcoal resulted in $40 \%$ of contamination $\left(E_{1}\right)$. When only charcoal was used $\left(E_{3}\right)$, the contamination reached $56 \%$. The control $\left(\mathrm{E}_{4}\right.$, no chlorine and no charcoal) presented $66 \%$ of contaminated explants.

Bacterial contamination was also variable among treatments. The lowest contamination rate after 63 days was observed in treatment $\mathrm{E}_{1}$, containing both active chlorine and charcoal (figure 2C). Conversely, when only active chlorine was used $\left(\mathrm{E}_{2}\right), 56 \%$ of the explants were contaminated with bacteria. The control treatment resulted in $58 \%$ of contaminated explants. The highest bacterial contamination (66\%) was observed from $\mathrm{E}_{3}$, with only charcoal (figure 2C).

The in vitro establishment of the explants of $B$. vulgaris (explants with no fungal or bacterial contamination) was progressively reduced over time, with the subsequent cultivations. Low rates of establishment were recorded at the end of the experiment $(<10 \%$ at 63 days of in vitro cultivation). The culture medium that provided the highest establishment rate $(16 \%)$ after 63 days was $\mathrm{E}_{2}$, supplemented only with active chlorine. A $10 \%$ establishment rate was the result of the cultivation in culture medium supplemented only with charcoal $\left(\mathrm{E}_{3}\right)$. The percentage of establishment was lower when both chlorine and charcoal were combined $(8 \%)$. No establishment was observed with the control treatment (0\%) (figure 2D).

The survival of the explants was progressively reduced over time (figure $2 \mathrm{E}$ ). Only $26 \%$ of the explants survived with the control treatment (no chlorine and no charcoal $-E_{4}$ ) at the end of the experiment. Higher survival rates were observed, though, when active chlorine or activated charcoal were applied separately or combined. The application of only active chlorine $\left(\mathrm{E}_{1}\right)$ resulted in the highest survival $(68 \%)$. The combination of both compounds $\left(\mathrm{E}_{2}\right)$ resulted in $42 \%$ of survival, while $38 \%$ was observed from the treatment with charcoal only $\left(\mathrm{E}_{3}\right)$ (figure $2 \mathrm{E}$ ).

The use of active chlorine and charcoal was beneficial for the induction of sprouts in B. vulgaris (figure $2 \mathrm{~F}$ ). The highest percentage was observed in the culture medium containing the combination of both compounds, resulting in $89 \%$ of explants with sprout induction after 21 days and $95 \%$ after 63 days of cultivation. The explants cultivated in culture medium supplemented only with active chlorine $\left(\mathrm{E}_{2}\right)$, presented $91 \%$ of sprout induction. In the treatment without chlorine, the explants presented lower percentage of sprouting, resulting in $73 \%$ when only charcoal was used $\left(\mathrm{E}_{3}\right)$ and $61 \%$ for the control treatment (figure $2 \mathrm{~F}$ ).

In this work, we did not aim at testing different plant growth regulators and their effects on adventitious rooting (auxins). However, after 63 days of in vitro cultivation, some explants were selected as viable for the multiplication stage, as they presented more than three sprouts (figure 4A). Nodal segments were isolated from the explants (figure 4B), and inoculated in culture medium for the multiplication of the axillary buds. The development of the axillary buds was evaluated after 21 days (figure 4C). After 36 days of cultivation, we observed the development of spontaneous adventitious roots in a few of the explants $(<10 \%)$ in the in vitro condition (figure 4D). The propagules were afterwards submitted to ex vitro conditions in a growth chamber aiming at acclimatization (figure 4E).

Histological analysis. The histological sections of the nodal segments of $B$. vulgaris showed the presence of meristematic regions, cells of leaf primordia, stem apical meristem and groups of compacted cells. Such elements are presented in figure $5 \mathrm{~A}$. A high number of fibers were also observed (figure 5B). The disposition of the cortex, parenchyma and the vascular tissues are presented in figure $5 \mathrm{C}$.

The stem and leaves were observed as continuous structures. The vascular tissue of the stem connects with the leaf vascular tissue, where one or more stem bundles diverge to the leaf, which might present smaller quantities of trichomes, showing normal growth and development (figure 6).

A further observation from the histological analysis was performed on the region of emergence of the adventitious roots. It occurred in association with the axillary buds (figure 7A). The adventitious roots were analyzed, from which we identified the medulla (figure 7B) and the presence of root hair (figure 7C), which facilitate the entrance of solutes to the plant. We also observed the epidermis, parenchyma, endodermis and the vascular system (figure 7D). 


\section{DISCUSSION}

In vitro oxidation, contamination, survival and establishment. Our results revealed the effectiveness of using active chlorine for reducing contamination in bamboo explants. Nevertheless, the use of activated charcoal presented no effect in reducing oxidation, as $100 \%$ of the materials were oxidized after 42 days of in vitro cultivation. The oxidation process is commonly associated with mechanisms of tissue cicatrization, which promote exudation of phenolic compounds in response to the injuries in the explants during their preparation and in vitro inoculation (Mudoi et al. 2013). The severity of the darkening (i.e., necrosis) of the explant might vary according to factors such as the bamboo species, the tissue or organ chosen as the explant and the culture medium (Huang et al. 2002), the seasonality of the propagule collection (Singh et al. 2013). As the sources of explants were transported through a long distance, it also contributed to accelerating the oxidation process.
Despite oxidation commonly represents a negative impact to the in vitro cultivation of forest species (Huang et al. 2002, Silva et al. 2015), the explants of B. vulgaris of this study were still able to develop sprouts. The oxidation caused no damage to the axillary buds and the emerged sprouts (figure 3). Bamboo species have shown proclivity to oxidation, which not necessarily implicates in the mortality of the propagated materials (Mudoi et al. 2013).

Another limiting factor on the propagation of bamboos has been the high contamination with fungi and bacteria, compromising the development of the propagules. Fungal and bacterial contamination commonly affects the initial stage of the in vitro cultivation, compromising the continuity of the propagation (Ramanayake et al. 2006). Contamination has been an issue for large-scale production of species of economic interest (Singh et al. 2013). Therefore, we supplemented the culture medium with active chlorine and achieved considerable reduction in the contamination rate.

In general, active chlorine has been used in the asepsis stage before inoculation (Teixeira et al. 2006, Brondani et



Figure 4. Details of the multiplication stage showing the sprout sectioning, in vitro adventitious rooting and acclimatization of Bambusa vulgaris explants. (A) Explant presenting multiple sprouts after 63 days of cultivation. (B) Nodal segments sectioned and selected for the multiplication of sprouts. (C) Detail of the in vitro sprouting after 21 days of cultivation. (D) In vitro adventitious rooting after 36 days of cultivation. (E) Cloned plant in acclimatization. Bar $=1 \mathrm{~cm}$.

Detalles de la etapa de multiplicación que muestra la sección del brote, el enraizamiento adventicio in vitro y la aclimatación de los explantes de Bambusa vulgaris. (A) Explantes que presentan múltiples brotes después de 63 días de cultivo. (B) Segmentos nodales seccionados y seleccionados para la multiplicación de brotes. (C) Detalle del brote in vitro después de 21 días de cultivo. (D) Enraizamiento adventicio in vitro después de 36 días de cultivo. (E) Planta clonada en aclimatación. Barra $=1 \mathrm{~cm}$. 
al. 2013). Active chlorine is an effective compound toward the suppression of bacteria, fungi and their spores, virus and protozoa, exhibiting deleterious effects on microorganisms (Teixeira et al. 2006). It has been used in replacement to other compounds that are of much toxic effect, such as the mercury chloride $\left(\mathrm{HgCl}_{2}\right)$ and antibiotics ( $\mathrm{Ji}$ ménez et al. 2006, Brondani et al. 2013).

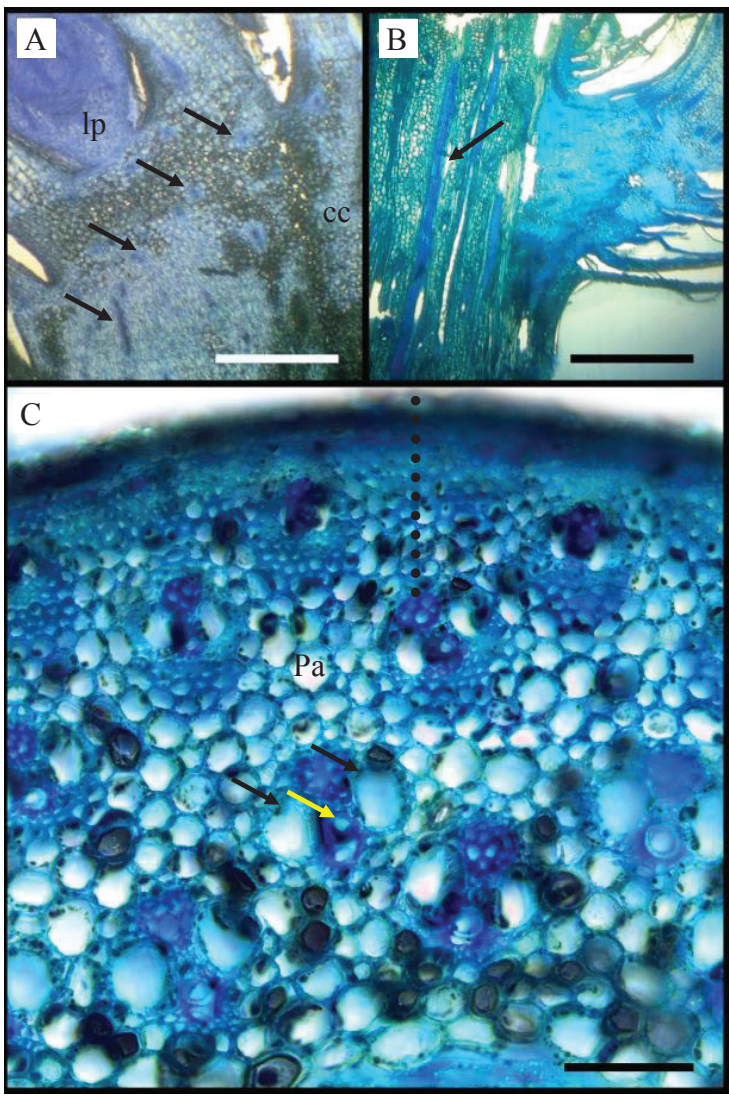

Figure 5. Anatomic structure of a nodal segment of Bambusa vulgaris. (A) Longitudinal section of the axillary bud evidencing cells ofleafprimordia (lp), groups of compacted cells (cc). The arrows indicate the presence of multiple meristematic regions. $\mathrm{Bar}=200 \mu \mathrm{m}$. (B) Longitudinal profile of the node containing the axillary bud. The arrow indicates de the presence of fibers. Bar $=200 \mu \mathrm{m}$. (C) Transversal section of the nodal segment, with the dotted line evidencing the cortex (epidermis and hypodermis) and parenchy$\mathrm{ma}(\mathrm{Pa})$. Details of the vascular system, with the black arrow indicating xylem and the yellow arrow the phloem. Bar $=100 \mu \mathrm{m}$. Source: figure 5A according to Brondani et al. (2017).

Estructura anatómica de un segmento nodal de Bambusa vulgaris. (A) Sección longitudinal de la yema axilar que evidencia células de primordios foliares (lp), grupos de células compactadas (cc). Las flechas indican la presencia de múltiples regiones meristemáticas. Barra $=200 \mu \mathrm{m}$. (B) Perfil longitudinal del nodo que contiene la yema axilar. La flecha indica la presencia de fibras. Barra $=200 \mu \mathrm{m}$. (C) Sección transversal del segmento nodal, la línea discontinua que evidencia la corteza (epidermis y hipodermis) y parénquima ( $\mathrm{Pa}$ ). Detalles del sistema vascular, con la flecha negra indicando el xilema y la flecha amarilla. Barra $=100 \mu \mathrm{m}$. Fuente: figura 5A de acuerdo con Brondani et al. (2017).
The use of active chlorine in our study implicated in partial elimination of the contamination with microorganisms. Similarly, contamination with microorganisms has been variable among different studies with bamboos using active chlorine, such as $55 \%$ in Bambusa ventricosa McClure (Wei et al. 2015), $80.5 \%$ (Garcia et al. 2004), $91 \%$ (Marulanda et al. 2002) and $95 \%$ (Jiménez et al. 2006) in Guadua angustifolia Kunth and $100 \%$ in Bambusa tulda Roxb (Mishra et al. 2008). Similarly, the microbial contamination was reduced to $55 \%$ in $B$. ventricosa with Na$\mathrm{ClO}$ and to $20 \%$ with $\mathrm{HgCl}_{2}$ (Wei et al. 2015). Therefore, the responses of the explants to germicides also depend on the bamboo provenance and the genotype used for propagation (Brondani et al. 2013), as the gene expression machinery of each genotype confers distinct resistance degrees to the microorganisms.

The high rates of contamination reported by different studies might be associated with endophytic microorganisms from bamboos (Singh et al. 2013) that are exuded to the culture medium after tissue sectioning, compromising the development of the explant and reducing the in vitro survival of the plant material. Contamination by fungi fully compromises the explants; however, bacterial contamination or later manifestation might be controlled under certain conditions, occasionally enabling the continuity of the cultivation of the explant.

Besides reduction in contamination rates, the use of active chlorine might have had a positive effect on the survival of the explants of $B$. vulgaris. $\mathrm{Cl}^{-}$is considered an essential ion, which influences the photosynthetic reactions and cleavage of the water molecule, releasing oxygen (Her-

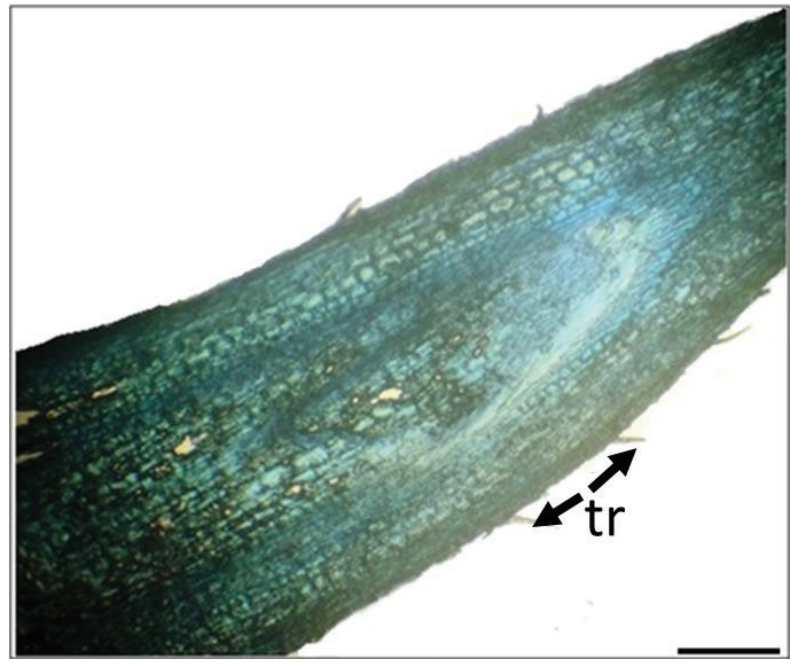

Figure 6. Longitudinal section of one leaf primordium of Bambusa vulgaris. The arrow indicates the presence of trichomes (tr) on the epidermis. $\mathrm{Bar}=200 \mu \mathrm{m}$.

Sección longitudinal de un primordio de hoja de Bambusa vulgaris. La flecha indica la presencia de tricomas (tr) en la epidermis. Barra $=200 \mu \mathrm{m}$. 




Figure 7. Anatomic structure of adventitious root from Bambusa vulgaris. (A) Transversal section of the connection between the adventitious root $(\mathrm{Ra})$ with the nodal segment $(\mathrm{SeN})$ as indicated by the arrow. (B) Longitudinal section evidencing the medulla (me). (C) Transversal sections of the root. The arrow indicates the presence of root hair on the adventitious roots $(\mathrm{Bar}=200 \mu \mathrm{m})$. (D) Transversal sections of the root evidencing details of the epidermis in green arrows. The parenchyma (Pa) and endodermis are indicated by the yellow arrow. The vascular system is indicated with the black arrow. Bar $=100 \mu \mathrm{m}$.

Estructura anatómica de raíz adventicia de Bambusa vulgaris. (A) Sección transversal de la conexión entre la raíz adventicia (Ra) con el segmento nodal (SeN), como se indica por la flecha. (B) Sección longitudinal que evidencia el médula (me). (C) Sección transversal de la raíz, la flecha indica la presencia de raíz de pelo en las raíces adventicias (barra $=200 \mu \mathrm{m}$ ). (D) Sección transversal de la raíz que evidencia detalles de epidermis con la flecha verde, parénquima $(\mathrm{Pa})$, endodermis con la flecha amarilla y sistema vascular con la flecha negra. Barra $=100 \mu \mathrm{m}$.

dean et al. 2016). $\mathrm{Na}^{+}$stimulates the growth by intensifying cellular expansion (Bassil et al. 2012). Effectively, in our work, the highest survival rates were obtained when active chlorine was added to the culture medium ( $68 \%$ when only chlorine was supplemented to the culture medium and $42 \%$ with the supplementation of both chlorine and charcoal). It might also have contributed to the higher percentage of sprout induction (91\% of explants) from the medium with supplementation of chlorine only. Other studies have reported similar trends, implying beneficial effects from the use of chlorine in sprout induction and vigor of the explants of bamboos (Garcia et al. 2004).

Despite the beneficial effects of active chlorine in the reduction of contamination and increase of survival and sprouting, low rates of explant establishment were achieved in our study, as well as frequently reported by others. The highest rates of establishment (16\%) were achieved with the treatment with only active chlorine, once more corroborating its beneficial effect toward the in vitro cultivation of $B$. vulgaris. Therefore, we recommend that the culture medium should be supplemented with active chlorine $(0.004 \%)$ in order to achieve better results for the in vitro propagation of the species. Such recommendation might also be extended to other bamboo species, as well as other trees. However, further assessment of methods for more effective reduction of the contamination and higher establishment of explants is necessary.

Spontaneous occurrence of adventitious rooting. At 63 days of cultivation, a few explants were selected for the multiplication phase, as they presented more than three sprouts $(<$ $10 \%$ of the explants) (figure $4 \mathrm{~A}$ ). After $36 \mathrm{~d}$, we observed the development of adventitious roots in a few of the sprouts cultivated in the multiplication medium. Subsequently, the 
sprouts were submitted to ex vitro conditions for acclimatization. The adventitious rooting occurred without supplementation of the culture medium with plant growth regulators of the auxin group such as indole-3-butyric acid (IBA) and might be explained by the accumulation of endogenous auxins in the explants (Ramanayake et al. 2006). The natural auxin accumulation might have increased metabolic rates and promoted the development of adventitious roots on the sprouts (Kapoor and Rao 2006). Low rooting rates are major issues encountered during the in vitro culture of bamboo (Ramanayake et al. 2006, Singh et al. 2013); necrosis may occur in some cases (Kapoor and Rao 2006). However, the development of spontaneous adventitious roots was also observed in nodal segments of Bambusa bambos var. gigantea Bennet and Gaur (Kapoor and Rao 2006) and $G$. angusifolia (Jiménez et al. 2006). The use of charcoal in the culture medium may have contributed to the rooting of the explant, as it conditioned it to a darker environment, suitable for the emergence of roots (George et al. 2008). Nevertheless, further work is required to effectively test for adventitious rooting ability of explants containing axillary buds of $B$. vulgaris, as protocols for such purpose remain scarce for the species. Concentrations of plant growth regulators such as IBA and $\alpha$-naphthalene acetic acid (NAA) combined with cytokinins need to be tested for such goal (Singh et al. 2013).

Histological analysis. The anatomical analysis revealed that the explants contained the basic cell structure necessary for the development of new sprouts and roots. Histological sections of the nodal segments of B. vulgaris showed evidence of the presence of meristematic regions, cells of leaf primordia, stem apical meristem and groups of compacted cells, as shown in figure 5. The top of the bamboos presents only primary growth divided into the following regions: cortex, parenchyma and vascular bundles, in which the cortex covers the epidermis and hypodermis (Ray et al. 2004).

A high number of fibers were also observed (figure 5B). Fibers are made of sclerenchymatic tissue and are characterized by their long, tapered, forked shape and thickened walls, composed of lignin and various microfibril layers. The fibers contribute for structural support and flexibility of the stems (Ray et al. 2004).

The connection between the vascular system of the stem and the leaves, where one or more vascular bundles are oriented to the leaves, was evidenced from the histological sections (figure 7A). Therefore, stem and leaves are continuous structures. The presence of trichomes was evident from the histological analysis (figure 7C). Trichomes are common structures in bamboo leaves (Soderstrom and Ellis 1988), and the presence of smaller quantities of trichomes is a common feature observed in explants cultivated in vitro (Machado et al. 2014).

The explants that developed adventitious roots were analyzed with light microscopy. The emergence of the root occurred from the nodal region in association with the axillary buds. Adventitious roots are encountered in all vascular plants, although in bamboos, they are generally originated from the stem (Kapoor and Rao 2006). We observed that the adventitious root arises at the nodal segment connection (Figure 7A), and its anatomical structure is systematically organized, beginning with the epidermis, cortex, vascular tissues and the medulla. We also observed root hair on the histological sections (figure 7C). Root hairs are important structures as they increase the surface area of the root, enabling a more efficient absorption of water and nutrients (Libault et al. 2010). They showed normal growth and development.

\section{CONCLUSIONS}

The active chlorine promoted the reduction of fungal and bacterial contamination of the explants and increased the survival and development of sprouts from the explants. The activated charcoal promoted no effect in avoiding the oxidation of the materials; however, the oxidation caused no damage to axillary buds and sprouts of $B$. vulgaris.

From the experiments, we obtained a single explant with adventitious rooting, even without the application of plant growth regulators. Such event was used in a histological characterization, showing evidences of the presence of meristematic regions and the emergence of adventitious roots from the nodal region in association with axillary buds.

Our protocol might be potentially applicable for the in vitro propagation of $B$. vulgaris aiming at the cloning of selected adult matrices of $B$. vulgaris, as well as other bamboos. Further tests are necessary to improve explant establishment and promote adventitious rooting of the materials.

\section{ACKNOWLEDGMENTS}

To the National Counsel of Technological and Scientific Development - CNPq (Furlan, F.C.; Konzen, E.R.), Coordination for Improvement of Higher Education Personnel - CAPES (Gavilan, N.H.; Oliveira, L.S.) and PAEC OEA/GCUB (Zorz, A.Z.) for the financial support and scholarships for the students.

\section{REFERENCES}

Bakshi M, C Tiwari, S Razvi. 2015. Conservation of an important montane bamboo Thamnocalamus falconeri, Hook.f. ex Munro trough axillary bud proliferation. Journal of $\mathrm{Fo}_{\mathrm{O}}$ rest Research 26(1): 179-185.

Bassil E, A Coku, E Blumwald. 2012. Cellular ion homeostasis: emerging roles of intracellular $\mathrm{NHX} \mathrm{Na} / \mathrm{H}^{+}$antiporters in plant growth and development. Journal of Experimental Botany 63(16): 5727-5740.

Brondani GE, LS Oliveira, FC Furlan, AS Ribeiro. 2017. Estabelecimento in vitro de Bambusa vulgaris Schrad. ex J. 
C. Wendl e Dendrocalamus asper (Schult. et Schult. F.) Backer ex K. Heyne. In Drumond PM, G Wiedman eds. Bambus no Brasil: da biologia à tecnologia. Rio de Janeiro, Brasil. ICH. p. 86-102.

Brondani GE, LS Oliveira, T Bergonci, AE Brondani, FAM França, ALL Silva, AN Gonçalves. 2013. Chemical sterilization of culture medium: a low cost alternative to in vitro establishment of plants. Scientia Forestalis 41(98): 257-264.

Garcia MB, C Ros, Y Castellanos, M Silvio, RV Feria. 2004. Efecto de diferentes métodos de desinfección en el establecimiento in vitro de Guadua angustifolia Kunth. Biotecnología Vegetal 4(4): 237-242.

George EF, MA Hall, GJ de Klerk. 2008. Plant propagation by tissue culture. v. 1. $3^{\mathrm{a}}$ ed. Dordrecht, Netherlands. Springer. $501 \mathrm{p}$.

Herdean A, E Teardo, AK Nilsson, BE Pfeil, ON Johansson, R Ünnep, G Nagy, O Zsiros, S Dana, K Solymosi, G Garab, I Szabó, C Spetea, B Lundin. 2016. A voltage-dependent chloride channel fine-tunes photosynthesis in plants. Nature Communications 7(11654): 1-11.

Huang LC, YL Lee, BL Huang, CI Kuo, JF Shaw. 2002. High polyphenol oxidase activity and low titratable acidity in browning bamboo tissue culture. In Vitro Cellular \& Developmental Biology - Plant 38(4): 358-365.

Jiménez VM, J Castilho, E Tavares, E Guevara, M Montiel. 2006. In vitro propagation of the neotropical giant bamboo, Guadua angustifolia Kunth, through axillary shoot proliferation. Plant Cell, Tissue and Organ Culture 86(3): 389-395.

Kapoor P, IU Rao. 2006. In vitro rhizome induction and plantlet formation from multiple shoots in Bambusa bambos var. gigantea Bennet and Gaur by using growth regulators and sucrose. Plan Cell, Tissue and Organ Culture 85(2): 211-217.

Karnovsky MJ. 1965. A formaldehyde-glutaraldehyde fixative of high osmolality for use in electron microscopy. Journal of Cell Biology 27(2): 137-138.

Libault M, L Brechnmacher, J Cheng, D Xu, G Stacey. 2010. Root hair systems biology. Trends in Plant Science 15(11): 641-650.

Machado MP, ALL Silva, LA Biasi, C Deschamps, JC Bespalhok Filho, F Zanette. 2014. Influence of calcium content of tissue on hyperhydricity and shoot-tip necrosis of in vitro regenerated shoots of Lavandula angustifolia Mill. Brazilian Archives of Biology and Technology 57(5): 636-643.

Marulanda ML, P Marquez, X Londono. 2002. AFLP analysis of Guadua angustifolia (Poaceae: Bambusoideae) in Columbia with emphasis on the coffee region. Journal of the American Bamboo Society 16(1): 32-42.

Mishra Y, PK Patel, S Yadav, F Shirin, AS Ansari. 2008. A micropropagation system for cloning of Bambusa tulda Roxb. Scientia Horticulture 115(3): 315-318.

Mudoi KD, SP Saikia, A Goswami, A Gogoi, D Bora, M Borthakur. 2013. Micropropagation of important bamboos: a review. African Journal of Biotechnology 12(20): 27702785 .

Murashige T, F Skoog. 1962. A revised medium for rapid growth and bioassays with tobacco tissue cultures. Physiologia Plantarum 15(3): 473-497.

Ray AK, SK Das, S Mondal, P Ramachandrarao. 2004. Microstructural characterization of bamboo. Journal of Materials Science. 39(3): 1055-1060.

Ramanayake SMSD, VN Meemaduma, TE Weerawardene. 2006. In vitro shoot proliferation and enhancement of rooting for the large-scale propagation of yellow bamboo (Bambusa vulgaris Striata). Scientia Horticulturae 110(1): 109-113.

Sakai WS. 1973. Simple method for differential staining of paraffin embedded plant material using toluidine blue O. Stain Technology 48(5): 247-249.

Silva ALL, AL Gollo, GE Brondani, MA Horbach, LS Oliveira, MP Machado, KKD Lima, JL Costa. 2015. Micropropagation of Eucalyptus saligna Sm. from cotyledonary nodes. Pakistan Journal of Botany 47(1): 311-318.

Singh SR, R Singh, S Kalia, S Dalal, AK Dhawan, RK Kalia. 2013. Limitations, progress and prospects of application of biotechnological tools in improvement of bamboo - a plant with extraordinary qualities. Physiology and Molecular Biology of Plants 19(1): 21-41.

Soderstrom TR, RP Ellis. 1988. The position of bamboo genera and allies in a system of grasses classification. In Soderstrom TR, KW Hilu, CS Campbell, ME Barkworth eds. Grass systematics and evolution. Washington DC, USA. Smithsonian Institution Press. p. 225-238.

Teixeira SL, JM Ribeiro, MT Teixeira. 2006. Influence of $\mathrm{NaClO}$ on nutrient medium sterilization and on pineapple (Ananas comosus cv Smooth cayenne) behavior. Plant Cell, Tissue and Organ Culture 86(3): 375-378.

Wei Q, J Cao, W Qian, M Xu, Z Li, Y Ding. 2015. Establishment of an efficient micropropagation and callus regeneration system from the axillary buds of Bambusa ventricosa. Plant Cell, Tissue, and Organ Culture 22(1): 1-8. 